\title{
Occurrence of meiofauna in Phaeocystis seafoam
}

\author{
Werner Armonies \\ Biologische Anstalt Helgoland, Litoralstation, D-2282 List/Sylt, Federal Republic of Germany
}

\begin{abstract}
Seafoam formed by wave action from the remainders of colonial Phaeocystis globosa may contain high numbers of meiofauna. In foam collected in the Wadden Sea near the Island of Sylt (FRG) in June 1988, the harpacticoids (Copepoda) Tachidius discipes and Harpacticus flexus dominated in abundance. Both species rest in superficial sediment layers at low tide and swim in the water column at high tide, preferentially at night. From the water column they pass into the foam, together with some planktonic species. Currently it is not clear if they actively enter the foam or become passively enclosed. Field experiments indicated that Phaeocystis colonies and foam may influence their diurnal activity rhythms. Possibly these species feed on organic compounds of the foam or on enclosed micro-organisms. Occasionally other benthic taxa also occurred in the foam. Once in the foam, these specimens may become dispersed, over wide areas.
\end{abstract}

Over the past decades, blooms of planktonic alga occurred increasingly frequently and intensively in the coastal zones of the North Sea, presumably due to nutrient enrichment from river discharge (Cadée \& Hegeman 1986, Radach \& Berg 1986, Veldhuis et al. 1986). The increase in phytoplankton biomass is mainly caused by flagellates while diatom biomass remained rather constant (Radach \& Berg 1986). Presumably diatom abundance is controlled by silicate concentrations (Officer \& Ryther 1980) which did not significantly change during the past decades (Lancelot et al. 1987). Thus mainly flagellates benefit from nutrient enrichment, above all species like Phaeocystis globosa Scherffel (Prymnesiophyceae) which had been preadapted to blooming (Lancelot et al. 1987). Phaeocystis may occur in a motile and a colonial form. The latter consists of colonies of cells in a common gelatinous matrix composed of polysaccharides; the polymeric structure of the mucus makes it subject to foaming by wave action (Lancelot et al. 1987). Until collapsed the foam is stable over some hours to about a day (own obs.). During this period it may accumulate on beaches or drift with tidal currents. Organisms enclosed in the foam may thus be dispersed over considerable distances. Since seafoam contains carbo-

c) Inter-Research/Printed in F. R. Germany hydrates and other dissolved organic substances (Eberlein et al. 1985, Bärlocher et al. 1988) it might be an attractive source of food for small fauna, either by direct ingestion of foam, or via micro-organisms. On the other hand, the foam might be harmful to species caught involuntarily in the foam and unable to survive there.

Material and methods. Between 15 and 26 June 1988, seafoam, seawater, and sediment samples were collected at a sheltered intertidal sandflat and several beaches near the Island of Sylt (FRG) in the northern Wadden Sea, and offshore between the Island of Sylt and the Danish island Rømø. Foam deposited on the shore was packed into plastic boxes of $500 \mathrm{~cm}^{3}$ with a trowel without touching the sediment underneath. Floating foam was scooped with buckets and separated from the enclosed seawater. Superficial sediment of the tidal flat was sampled with glass tubes of $1 \mathrm{~cm}^{2}$ inserted to a depth of $1 \mathrm{~cm}\left(=1 \mathrm{~cm}^{3}\right.$ per sample). Seawater samples of $100 \mathrm{~cm}^{3}$ were scooped with glass jars of this size from the superficial water layer (top $10 \mathrm{~cm}$ ) in the area of foam formation.

In the laboratory, the foam was transferred into $1.5 \mathrm{dm}^{3}$ separating funnels and repeatedly washed with filtered seawater. The water was drained through a tap at the lower part of the funnel and filtered through $63 \mu \mathrm{m}$ meshes to retain enclosed meiofauna. Seawater samples were filtered through the same sieve and the sediment samples were extracted by a shaking-rotating procedure (Noldt \& Wehrenberg 1984) without using anaesthetics (Armonies \& Hellwig 1986). The separated fauna was sorted into dead and living animals using a stereomicroscope and determined using a compound microscope if necessary (after fixation, in some cases).

Samples of Phaeocystis foam are difficult to quantify. Freshly formed foam is bright in colour (pale yellowish), and while aging it becomes yellowish and finally grey. At the same time its volume reduces by more than 
an order of magnitude and enclosed particles (including organisms) concentrate in the remaining volume. Therefore statistical comparisons of absolute abundances per volume unit of foam cannot be used. Instead, the taxonomic composition of the fauna enclosed in foam from different sites was analysed and relative abundances were compared by Wilcoxon's matched pair signed rank statistic and by maximum tests (Sachs 1984).

Active swimming of harpacticoids and other benthic taxa correlates with light intensity, with the highest swimming activity in the dark (Armonies 1988a, b, in press). Both dense aggregates of Phaeocystis colonies and foam shade the sediment and might thus alter the diurnal activity rhythms. Two field experiments tested for such an influence.

(1) When a patch of Phaeocystis colonies occurred nearshore with the incoming tide, 10 water samples of $500 \mathrm{~cm}^{3}$ each were collected from the edge to the center of the Phaeocystis patch (9 June). Water depth was 50 to $60 \mathrm{~cm}$. The seawater was collected using a $10 \mathrm{~cm}^{2}$ glass pipe of $50 \mathrm{~cm}$ length which was vertically inserted into the water column without touching the sediment, closed at both ends, and removed. The enclosed seawater was sieved through $63 \mu \mathrm{m}$ meshes and the retained meiofauna evaluated as above. The density of Phaeocystis colonies was estimated by the transparency of the water column (relative scale according to the water depth through which the lower end of the glass pipe could no longer be seen; max. = $50 \mathrm{~cm}$, min. $=6 \mathrm{~cm}$ ). Results are evaluated using Spearman's rank correlation coefficient.

(2) The second experiment tested whether short-time $(3 \mathrm{~min})$ shading of the sediment results in increased harpacticoid abundance in the water column. On 12 June (daytime, no clouds, incoming tide) 2 transparent plastic aquaria were placed upside down onto the sediment of the intertidal sandflat (same site as for seafoam collection). The bottom (now uppermost) of both aquaria was pierced and a glass pipe of $50 \mathrm{~cm}$ length and $40 \mathrm{~mm}$ outer diameter was passed vertically through the holes (Fig. 1). A cushion of wire netting prevented direct contact between the sediment and the glass pipe. The first aquarium and glass pipe were covered with aluminium foil to prevent entry of light. The sediment below this aquarium was strongly shaded. The other aquarium and glass pipe remained transparent. In the field the plastic aquaria were placed onto the sediment close to each other. Then the glass pipes filled with filtered seawater (top of the pipe closed by a stopper, lower end open) were passed through the holes and held in place. Animals leaving the sediment below the pipes and still swimming in the water column after 3 min were trapped when the pipes were removed from the aquaria and closed below the

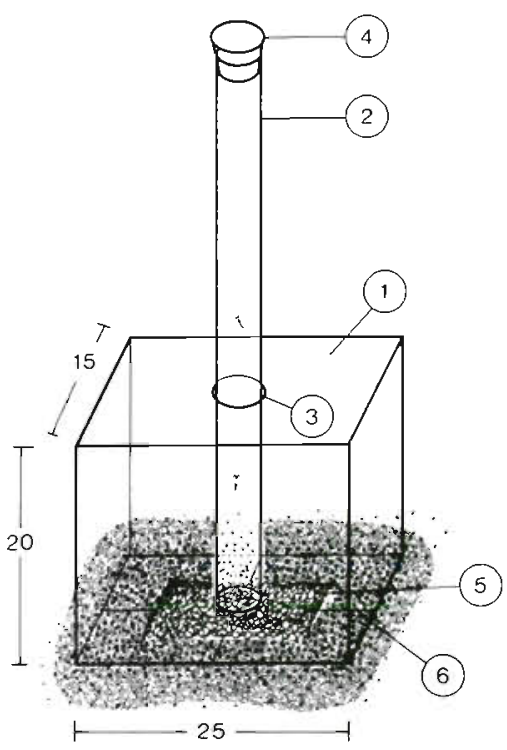

Fig. 1. Experimental shading of sediment in the field. A plastic aquarium (1) is placed upside down onto the sediment. A glass pipe (2) filled with filtered seawater is passed through a hole (3) in the bottom of the aquarium. The top opening of the pipe is closed by a stopper (4). A cushion of mesh wire (5) fixed to the walls of the aquarium (6) prevents direct contact between the glass pipe and the sediment. One aquarium remained transparent, and the other aquarium and glass pipe were covered with aluminium foil to shade the sediment. Dimensions of aquarium in $\mathrm{cm}$

water level. The fauna of the enclosed seawater was evaluated as before. This experiment carried out 15 times, each time in a formerly unused (undisturbed) part of the sandflat. Since there may be differences in the abundances of potential swimmers in the sediment of the experimental site and a possible time effect (the 15 -fold repetition took about $2 \mathrm{~h}$ ) results are analysed by Wilcoxon's matched pair signed rank statistics applied to the simultaneously performed replicates $\left(\mathrm{H}_{0}\right.$ : there is no difference between the number of animals emerging from the shaded and unshaded sediment).

Results. The number of meiofaunal organisms enclosed in Phaeocystis foam was lowest at the exposed western beach of the island and highest in foam formed above the intertidal sandflat (Table 1). Foam formed at the exposed beaches contained mainly planktonic taxa and benthic nematodes, while the foam from the sheltered tidal flat was dominated by harpacticoid copepods (Table 2). Appendicularians and nematodes were alive in fresh foam but all dead in collapsed foam from the exposed beach, indicating that they had been enclosed alive and then died. The percentages of appendicularians and calanoids were highest in foam from exposed and semi-exposed beaches; however, their lower percentage in foam from the sheltered sandflat and the adjoining beach was due to high 
Table 1. Mean abundance of metazoans $>63 \mu \mathrm{m}$ per $\mathrm{dm}^{3}$ of freshly formed (fresh), aged, and degenerated (old) Phaeocystis foam collected near the Island of Sylt in June 1988. $n$ : no. of samples

\begin{tabular}{|lrrrrrr}
\hline Locality & \multicolumn{2}{c|}{ Fresh } & Aged & Old \\
\hline Exposed beach & 2 & $(n=8)$ & 5 & $(n=8)$ & 13 & $(n=4)$ \\
Semi-exposed beaches & 6 & $(n=6)$ & 21 & $(n=1)$ & 38 & $(n=1)$ \\
Shelteres tidal flat & 233 & $(n=12)$ & 620 & $(n=8)$ & $160 \quad(n=1)$ \\
Offshore samples & 2 & $(n=1)$ & 560 & $(n=2)$ & & \\
\hline
\end{tabular}

Table 2. Percentage composition of the metazoan fauna enclosed in Phaeocystis foam from various localities near the Island of Sylt in June 1988

\begin{tabular}{|c|c|c|c|c|c|}
\hline Taxon & $\begin{array}{l}\text { Exposed } \\
\text { beach }\end{array}$ & $\begin{array}{c}\text { Semi-exposed } \\
\text { beach }\end{array}$ & $\begin{array}{l}\text { Shelteres } \\
\text { sandflat }\end{array}$ & I & II \\
\hline Appendicularia & 21.4 & 27.1 & 0.2 & - & - \\
\hline Calanoid copepods & 14.3 & 38.6 & 3.9 & $<0.1$ & 14.3 \\
\hline Polychaete larvae & 28.6 & 1.4 & 0.9 & 1.8 & 28.6 \\
\hline Barnacle nauplii & - & - & 5.3 & - & 7.1 \\
\hline Barnacle cypris-larvae & - & - & 1.0 & - & - \\
\hline Veliger-larvae & - & - & 7.7 & - & - \\
\hline Nematoda & 32.1 & 10.0 & 0.3 & - & - \\
\hline Ostracoda & - & 2.9 & 2.2 & - & - \\
\hline \multicolumn{6}{|l|}{ Harpacticoid copepods: } \\
\hline Tachidius discipes & - & - & 62.3 & 98.0 & 7.1 \\
\hline Harpacticus flexus & - & 11.4 & 13.5 & $<0.1$ & - \\
\hline Other harpacticoids & 3.6 & 7.2 & 1.6 & $<0.1$ & 42.8 \\
\hline Cyclopoid copepods & - & 1.4 & 0.2 & - & - \\
\hline Halacarida & - & - & 0.4 & - & - \\
\hline Others & - & - & 0.4 & $<0.1$ & - \\
\hline
\end{tabular}

abundance of other taxa, particularly harpacticoids. In the latter taxon the species Tachidius discipes Giesbrecht and Harpacticus flexus Brady \& Robertson were exceptionally abundant. Barnacle nauplii and cyprislarvae, veliger-larvae (mainly Littorina littorea L.) and halacarids were only found in foam sampled from artificial rock barriers constructed for coastal protection. These rocks are densely overgrown with barnacles and Littorina species are abundant. Ostracoda only occurred in foam which had drifted above the sediment surface on the incoming tides. Such foam also had an exceptionally high sediment load.

The origin of the offshore foam samples can only be inferred from the hydrographic conditions preceeding sample collection. Presumably, offshore foam II (Table 2) derived from the NE tip of the island of Sylt, which forms a transition zone between exposed and sheltered beaches. The specific composition of harpacticoids fits this assumption. The foam contained Halectinosoma gothiceps (Giesbrecht) and Pseudobradya beduina Monard, which were both also found in foam formed at the semi-exposed beaches. Offshore foam I was ca 2 to $4 \mathrm{~h}$ old when collected. The hydrographic situation preceeding sample collection indicates that this foam derived from a sandflat between the northern part of the Island of Sylt and the Danish mainland. Offshore foam I was strongly dominated by only 2 species, the harpacticoid Tachidius discipes and planktonic larvae of the polychaete genus Scolelepis.

Tachidius discipes was also a dominant species in foam from the sheltered sandflat. All foam samples combined, it was about 5 times more abundant than the co-occurring Harpacticus flexus. But this relation was not consistent over all of the 21 foam samples of the sandflat: each of both species was more abundant than the other in 10 samples. However, the 6 highest differences in absolute abundance of the 2 species were all in favour of $T$. discipes. This rejects the assumption that both species were equally abundant in the foam (maximum test, $p<0.05)$. In the water column and in the sediment the relations between the 2 species were the reverse: $H$. flexus was always significantly more abundant (Wilcoxon matched pair signed rank test, water column $p<0.01$, sediment $p<0.001$; Fig. 2 ).

The water samples collected from a patch of Phaeocystis colonies revealed a significant positive correlation between the density of Phaeocystis and the abundance of harpacticoids in the water column (Spearman's rank correlation coefficient, $r_{\mathrm{s}}=0.648$, $p<0.05$ ). All harpacticoids but one were Harpacticus 
Tachidius discipes

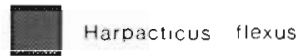

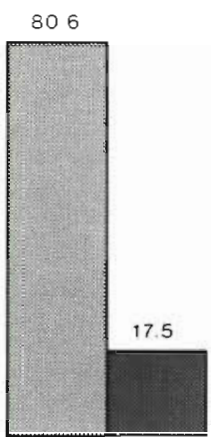

Foam

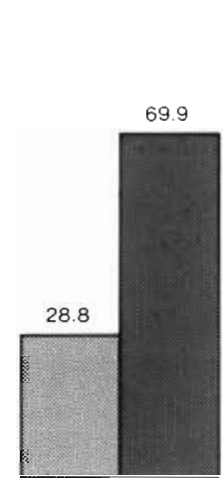

Water

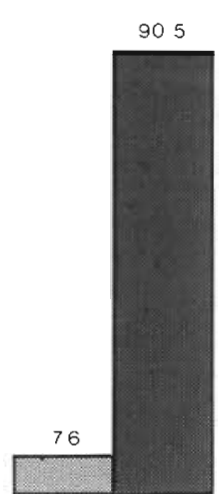

Sediment
Fig. 2. Percentages of dominant harpacticoid species in foam $\left(n=21\right.$ samples of $500 \mathrm{~cm}^{3}$, total no. of harpacticoids $N=1864)$, in the superficial water layer $\left(n=30 \times 100 \mathrm{~cm}^{3}\right.$, $N=236)$, and in the superficial sediment layer $(n=20 \times 1$ $\mathrm{cm}^{3}, N=1975$ )

flexus. Phaeocystis density did not correlate with any of the abundant planktonic taxa (calanoid copepods, barnacle nauplii, spionid larvae).

Experimental shading of the sediment caused a significant increase in harpacticoid numbers (mainly Harpacticus flexus and a few Tachidius discipes) in the water column (Wilcoxon's matched pair signed rank test, $R=14.5, n=13, p<0.05$ ). On average, 3 harpacticoids per $10 \mathrm{~cm}^{2}$ emerged from the unshaded and 8 per $10 \mathrm{~cm}^{-2}$ from the shaded sediment.

Discussion. The composition and abundance of the fauna enclosed in Phaeocystis foam seems to depend on (1) the intensity of wave action, (2) the faunal composition in the water column at the site of foam formation, and, presumably (3) the time (day versus night) of foam formation. (4) Once the foam is formed it may drift over tidal sediment with incoming tides or by wind action, or it may be deposited on the shore. In both cases additional specimens may find their way into the foam. (5) There may be species-specific preferences for foam, or alternatively, differences in the capability to leave the foam.

(1) The intensity of wave action correlates with the occurrence of appendicularians and nematodes in the foam. Both taxa were only abundant in foam formed at exposed or semi-exposed beaches. Most species of nematodes do not actively swim into the water column (Palmer 1988); presumably they need to be washed out of the sediment by strong wave action or currents to enter the foam. Appendicularians, however, were also abundant in the water column above the sheltered sandflat (unpubl. obs.). At this site with moderate wave action they seem to be able to avoid enclosure in the foam.
(2) With the exception of Harpacticus flexus and Tachidius discipes, all the remaining harpacticoid species found in foam from exposed and semi-exposed beaches are regarded as interstitial species (Mielke $1975,1976)$ which do not actively leave the sediment. Thus they can only be found in the foam when they were present at the site of foam formation.

(3) The harpacticoids Harpacticus flexus and Tachidius discipes pursue a semiplanktonic life-style (Armonies in press). They rest in superficial sediment layers during low tide and enter the water column at high tide. Both species prefer darkness for swimming and have a significantly higher abundance in the water column at night (Armonies 1988b, in press). Shading of the sediment, either experimentally or by high density of Phaeocystis colonies stimulates these night-active species to enter the water column during daytime. Presumably shading by foam may have the same effect. The resulting higher abundance of harpacticoids in the water column should result in a higher abundance in the foam, irrespective of the mode of entrance into the foam. The specimens might either become passively trapped or actively enter the foam, possibly attracted by shading or a chemical property of the foam. Further studies are needed to decide between these alternatives.

(4) Ostracoda only occurred in foam that was drifting above the sediment surface of the sandflat with the incoming tide. At the same time this foam was loaded with sediment. The ostracods of the studied sandflat are all epibenthic, i.e. they are active at the sediment surface when covered with water (Gottwald pers. comm.). Thus they easily become trapped in the foam. Barnacle nauplii and cypris-larvae, and veliger-larvae of Littorina littorea were only found in foam deposited on hard substrata. Since the adults were very common at these sites the larvae might have a higher density there than above soft bottoms. It is not known, however, whether the larvae were eroded from the rocks during foam formation, or if they actively entered the foam.

(5) The reverse relations of the abundances of Harpacticus flexus and Tachidius discipes in the sediment and water column on the one hand and in the foam on the other indicates possible species-specific differences in susceptibility to being trapped in the foam or in ability to leave the foam again. Both possibilities suspect that these harpacticoids were involuntarily trapped in the foam. However, seafoam (or the enclosed micro-organisms) could be a valuable source of food (Eberlein et al. 1985, Bärlocher et al. 1988). Therefore, species-specific differences in the attraction by foam or the ability to actively enter the foam might be an alternative explanation. Generally some harpacticoid species are able to feed on Phaeocystis (Hicks \& Coull 
1983). Whether this is also the case for $H$. flexus or $T$. discipes and whether they thus play a role in seafoam destruction remains to be tested. Their high abundance in foam and the lack of dead individuals even in old foam indicated that they are able to do so.

General considerations. Seafoam formed from the remainders of Phaeocystis colonies may be a vaiuable source of food for small organisms and the harpacticoids Harpacticus flexus and Tachidius discipes are potential feeders on the foam or enclosed micro-organisms. They might so contribute to seafoam destruction. Another potential advantage to actively entering the foam might be dispersal with tidal currents without the fear of being preyed upon by pelagic predators. However, the foam may be harmful to other species, as indicated by the dead appendicularians and nematodes in aged foam. The shading effect of dense aggregates of Phaeocystis colonies and, presumably, foam may disarrange the natural diurnal activity rhythms of semi-planktonic species and thus affect the entire community in a still unpredictable way. Further studies are needed to judge the effects of Phaeocystis blooms on the meiobenthic communities of shallow waters.

Acknowledgements. N. Kruse and P. Elvert of RV 'Mya' are thanked for collecting offshore foam samples. Thanks are due to $K$. Reise who improved the manuscript by critical comments. This study was supported by a grant of the Biologische Anstalt Helgoland.

\section{LITERATURE CITED}

Armonies, W. (1988a). Active emergence of meiofauna from intertidal sediment. Mar. Ecol. Prog. Ser. 43: 151-159

Armonies, W, (1988b). Physical factors influencing active emergence of meiofauna from boreal intertidal sediment. Mar Ecol. Prog. Ser. 49: 277-286

Armonies, W. (in press). Meiofaunal emergence from intertidal sediment measured in the field: significant contribu-

This note was submitted to the editor tion to nocturnal planktonic biomass in shallow waters Helgoländer Meeresunters. 43

Armonies, W., Hellwig, M. (1986). Quantitative extraction of living meiofauna from marine and brackish muddy sediments. Mar Ecol. Prog. Ser 29: 37-43

Bärlocher, F., Gordon, J., Ireland, R. J. (1988). Organic composition of seafoam and its digestion by Corophium volutator (Pallas). J. exp. mar Biol. Ecol. 115: 179-186

Cadée, G. C., Hegeman, J. (1986). Seasonal and annual variation in Phaeocystis pouchetii (Haptophyceae) in the westernmost inlet of the Wadden Sea during the 1973 to 1985 period. Neth. J. Sea Res. 20: 29-36

Eberlein, K., Leal, M. T., Hammer, K. D., Hickel, W. (1985). Dissolved organic substances during a Phaeocystis pouchetii bloom in the German Bight (North Sea). Mar. Biol. 89: 311-316

Hicks, G. R. F., Coull, B. C. (1983). The ecology of marine meiobenthic harpacticoid copepods. Oceanogr mar. Biol. A. Rev. 21: $67-175$

Lancelot, C., Billen, G., Sournia, A., Weisse, T., Colijn, F., Veldhuis, M. J. W., Davies, A., Wassman, P. (1987). Phaeocystis blooms and nutrient enrichment in the continental coastal zones of the North Sea. Ambio 16: 38-46

Mielke, W. (1975). Systematik der Copepoda eines Sandstrandes der Nordseeinsel Sylt. Mikrofauna Meeresbod. 52: $1-134$

Mielke, W. (1976). Ökologie der Copepoda eines Sandstrandes der Nordseeinsel Sylt. Mikrofauna Meeresbod. 59: $1-86$

Noldt, U., Wehrenberg, C. (1984). Quantitative extraction of living Plathelminthes from marine sands. Mar. Ecol. Prog. Ser, 20: 193-201

Officer, C. B., Ryther, J. H. (1980). The possible importance of silicon in marine eutrophication. Mar. Ecol. Prog. Ser. 3: $83-91$

Palmer, M. A. (1988). Dispersal of marine meiofauna: a review and conceptual model explaining passive transport and active emergence with implications for recruitment. Mar. Ecol. Prog. Ser. 48: 81-91

Radach, G., Berg, J. (1986). Trends in den Konzentrationen der Nährstoffe und des Phytoplanktons in der Helgoländer Bucht (Helgoland Reede Daten). Ber. Biol. Anst. Helgoland 2: $1-63$

Sachs, L. (1984). Angewandte Statistik. Springer, Berlin

Veldhuis, M. J. W., Colijn, F., Venekamp, L. A. H (1986). The spring bloom of Phaeocystis pouchetii (Haptophyceae) in Dutch coastal waters. Neth. J. Sea Res. 20:37-48

Manuscript first received: August 3, 1988

Revised version accepted: February 22, 1989 